\title{
Reporting quality of randomized controlled trials published in prosthodontic and implantology journals
}

\begin{tabular}{|c|c|}
\hline Journal: & Journal of Oral Rehabilitation \\
\hline Manuscript ID: & JOR-15-0093.R1 \\
\hline Manuscript Type: & Original Article \\
\hline Date Submitted by the Author: & $\mathrm{n} / \mathrm{a}$ \\
\hline Complete List of Authors: & $\begin{array}{l}\text { Kloukos, Dimitrios; University of Bern, Department of Orthodontics and } \\
\text { Dentofacial Orthopedics } \\
\text { Papageorgiou, Spyridon N.; University of Bonn, Department of } \\
\text { Orthodontics } \\
\text { Doulis, Ioannis; } 251 \text { Hellenic AF V.A. General Hospital, Department of } \\
\text { Orthodontics and Dentofacial Orthopedics } \\
\text { Petridis, Haralampos; UCL Eastman Dental Institute, Restorative Dentistry, } \\
\text { Prosthodontics } \\
\text { Pandis, Nikolaos; University of Bern, Department of Orthodontics and } \\
\text { Dentofacial Orthopedics }\end{array}$ \\
\hline Patient: & Non-specific (any) \\
\hline Condition: & Not applicable \\
\hline Co-morbidity: & Not applicable \\
\hline Content method: & prosthodontics, implantology \\
\hline Study method: & $\begin{array}{l}\text { randomized controlled trial, evaluation research / outcome assessment, } \\
\text { evidence-based medicine, systematic review }\end{array}$ \\
\hline
\end{tabular}

\section{SCHOLARONE ${ }^{\text {Tw }}$ \\ Manuscripts}




\title{
Reporting quality of randomized controlled trials published in prosthodontic and implantology journals
}

Running head: Reporting quality of RCTs in prosthodontics and implantology

Article Category: Original article

D. KLOUKOS* ${ }^{*}$ S.N. PAPAGEORGIOU ${ }^{\dagger}$, I. DOULIS ${ }^{\ddagger}$, H. PETRIDIS ${ }^{\S} \&$ N. PANDIS ${ }^{\natural}$

\begin{abstract}
Author affiliations
*Department of Orthodontics and Dentofacial Orthopedics, Faculty of Medicine, University of Bern, Bern, Switzerland,

${ }^{\dagger}$ Department of Orthodontics, School of Dentistry, University of Bonn, Bonn, Germany; Department of Oral Technology, School of Dentistry, University of Bonn, Bonn, Germany; Clinical Research Unit 208, University of Bonn, Bonn, Germany,

${ }^{*}$ Department of Orthodontics and Dentofacial Orthopedics, 251 Hellenic Air Force V.A. General Hospital, Athens, Greece,

${ }^{\S}$ Department of Restorative Dentistry, UCL Eastman Dental Institute, London, UK,

"Department of Orthodontics and Dentofacial Orthopedics, Faculty of Medicine, University of Bern, Bern, Switzerland; Private Practice, Corfu, Greece
\end{abstract}

CORRESPONDENCE Dr. Haralampos Petridis, Program Director, Master in Conservative Dentistry, Senior Clinical Lecturer, Department of Restorative Dentistry, UCL Eastman Dental Institute, Prosthodontic Unit, 256 Gray's Inn Road, London WC1X 8LD, UK.

E-mail: c.petridis@ucl.ac.uk 
SUMMARY The purpose of this study was to examine the reporting quality of randomized controlled trials (RCTs) published in prosthodontic and implantology journals. Thirty issues of 9 journals in prosthodontics and implant dentistry were searched for RCTs, covering the years 2005-2012: The Journal of Prosthetic Dentistry, Journal of Oral Rehabilitation, The International Journal of Prosthodontics, The International Journal of Periodontics \& Restorative Dentistry, Clinical Oral Implants Research, Clinical Implant Dentistry \& Related Research, The International Journal of Oral \& Maxillofacial Implants, Implant Dentistry and Journal of Dentistry. The reporting quality was assessed using a modified CONSORT statement checklist. Data were analyzed using descriptive statistics followed by univariable and multivariable examination of statistical associations $(\alpha=0.05)$. A total of 147 RCTs were identified with a mean CONSORT score of $69.4(\mathrm{SD}=9.7)$. Significant differences were found among journals with the Journal of Oral Rehabilitation achieving the highest score (80.6, $\mathrm{SD}=5.5)$ followed by Clinical Oral Implants Research (73.7, $\mathrm{SD}=8.3)$. Involvement of a statistician/methodologist was significantly associated with increased CONSORT scores. Overall, the reporting quality of RCTs in major prosthodontic and implantology journals requires improvement. This is of paramount importance considering that optimal reporting of RCTs is an important prerequisite for clinical decision-making.

KEYWORDS: randomized clinical trials, prosthodontics, dental implants 


\section{Introduction}

Reliable evidence is more likely consequent to sound design and methodology $(1,2)$. Among the various study designs the randomized controlled trial (RCT) is considered as the "gold standard" for assessing the effectiveness and safety of medical interventions. Nevertheless, RCTs are also prone to inadequacies and there is a substantial body of evidence in the biomedical literature, which indicates that the quality of many RCTs is suboptimal (3-6).

Accurate and transparent reporting of RCTs is prerequisite for the assessment of their internal validity and the clinical translation of their results (7). In an effort to improve and standardize reporting of RCTs the CONSORT (Consolidated Standards of Reporting Trials) guidelines were developed by the CONSORT group and are continuously being updated. The main CONSORT document consists of 25 items and sets standards on how and what should be included in an RCT report (2).

The CONSORT guidelines have been endorsed by over 580 journals (8) and there is evidence of a positive impact on RCT reporting (9). In dentistry reporting quality of RCTs has been assessed in a number of general and dental specialty journals (10-18), indicating that there is room for improvement. However, there is a lack of studies comparatively evaluating the completeness of reporting of recently published RCTs in prosthodontic and implantology using the CONSORT guidelines (2).

Therefore, the primary objective of this study was to evaluate the completeness of reporting of RCTs in prosthodontic and implantology journals using the CONSORT statement. A secondary aim was to identify factors associated with better reporting of RCTs.

\section{Materials and methods}

Four dental journals with emphasis on prosthodontics (The International Journal of Prosthodontics, Journal of Oral Rehabilitation, The Journal of Prosthetic Dentistry, The International Journal of Periodontics \& Restorative Dentistry), 4 dental implantology journals (Clinical Implant Dentistry \& Related Research, Clinical Oral Implants Research, Implant Dentistry, The International Journal of Oral \& Maxillofacial Implants) and 1 general dental journal with a predilection for prosthodontics (Journal of Dentistry) were included in the study. The selected journals had the highest impact factors of prosthodontic and implant dentistry journals based on 2009 data.

The contents of 30 issues of each journal from June 2012 backwards were searched for RCTs on humans. Supplemental issues were included in the search, but were not counted as an issue. Initially the abstract was read and any trials that were clearly RCTs were included. Other articles that used 

was given that a comparison of treatment groups was assessed prospectively, were further investigated to examine whether randomization was implemented. Studies that did not involve humans and studies, where it was concluded that no true randomization was implemented, were excluded. Screening and selection of studies were conducted independently by two authors (DK, SNP).

The information extracted from each article included journal and year of publication, region of publication (Europe, Americas or other region, based on the first author), ethical approval, statistical significance of main finding, number of authors, involvement of a statistician or methodologist, and whether the study was single- or multicenter. Involvement of a statistician or methodologist was ascertained by checking author affiliations (public health or epidemiology departments were considered as providing statistical assistance), author degrees (where provided), and information in the methods or acknowledgement sections of each paper.

A modified CONSORT checklist as presented by Tiruvoipati et al. (6) was used to evaluate the reporting completeness of RCTs. This checklist has 30 questions related to the CONSORT items excluding the first item of the CONSORT checklist (title and abstract), since the authors have to follow the instructions of the journal in preparing the abstract. The given score per item ranged from 1 to 3 , with $1=$ no description, $2=$ inadequate description and $3=$ adequate description. The scores for the 30 items were added, and a percentage score was calculated for each trial, whereas non- applicable items were not scored. A trial with adequate descriptions (score 3) for all items would receive a score of 90. All scores were converted to a percentage scale and therefore a score of 90 was equivalent to $100 \%$ in the percentage scale. When non-applicable items were identified (for example inability to blind the treatment provider) only the applicable items were considered for the calculation of the percentages. Therefore, a trial with only 28 applicable items, but adequate descriptions (score 3) for these, would receive a maximum score of 84 , corresponding to a percentage of $100 \%$.

Each RCT was also scored using the Jadad scale (19), allocating trials a score between zero (very poor) and five (rigorous). The Jadad scale includes three questions and each one of them is answered with either yes (1 point) or no (no point): (1) “Is the study described as randomized?"; (2) "Is the study described as double blinded?"; (3) "Is there a description of withdrawals and dropouts?". Two additional points, to reach a maximum score of 5 , are given (i) if the method of randomization is clearly described and appropriate or (ii) if the method of blinding is clearly described and appropriate. One or 
two points are subtracted if the method of randomization or the method of blinding is described, but is inappropriate.

Each included RCT was scored independently by 2 authors (DK, SNP), and subsequently results were compared and modified in order to arrive to a mutually agreed score. Discrepancies between the 2 authors (DK, SNP) were resolved by discussion. Before data extraction, a calibration exercise was performed between the two authors responsible for it (DK, SNP) with 80 randomly selected studies. Inter-rater agreement was evaluated for all extracted data with Cohen's kappa and any disagreements were resolved with discussion.

\section{Statistical Analysis}

Descriptive statistics were calculated for the modified CONSORT scores and tabulated by trial characteristics. The modified CONSORT scores were approximately normally distributed. Data were analyzed through linear regression modeling; univariable analysis was utilized to determine articles' characteristics associated with the modified CONSORT scores, whereas multivariable analysis was employed to adjust for possible confounders. A two-tailed P-value of 0.05 was considered statistically significant with a $95 \%$ confidence interval. Analyses were performed with the STATA ${ }^{\circledR}$ version 13.0 software (Stata Corporation, College Station, Texas, USA).

\section{Results}

From the 3667 articles that were originally screened 3520 were excluded for not adhering to the inclusion criteria, leaving 147 RCTs for detailed assessment (Appendix 1). Inter-rater agreement was found to be excellent (kappa 0.88, 95\% CI: 0.87-0.89). The included RCTs reported on a wide selection of topics ranging from surgical implant procedures and techniques, survival of implants and prostheses, biological responses, clinician's perspective of esthetics and patient satisfaction.

Table 1 displays the 147 RCTs tabulated by their characteristics. The journals contributing with the most RCTs were Clinical Oral Implants Research (31.3\%), followed by The International Journal of Oral and Maxillofacial Implants (16.3\%) and Journal of Dentistry (14.3\%). The majority of RCTs originated from Europe (58.5\%), were approved by an ethical committee (72.1\%) and reported statistically significant findings (59.2\%). Concerning the number of authors, most RCTs included four to six authors $(64.6 \%)$, whereas a statistician/methodologist was involved in $37.4 \%$ of the RCTs. Finally, the majority of RCTs were a multi-center effort (71.4\%). 
Table 2 displays the scores for all items on the modified CONSORT checklist. Description of pre-study sample size calculation was absent in the majority of the trials (64.0\%). No description of the random number generation was also evident in $32.7 \%$ of the trials. Allocation concealment was not reported in $61.9 \%$ of the studies, whereas details of personnel involved in sequence allocation, enrollment, and assignment were not described in $51.0 \%$ of those. Blinding of participants and treatment providers was not reported in $36.7 \%$ and $37.4 \%$ of the sample respectively. No description of blinding of assessors and analysts reached $61.9 \%$ and $89.8 \%$ respectively. Absence of a flow chart describing patient numbers at different stages of a study was apparent in $76.9 \%$ of the sample. Trial limitations and generalizability of the trial results were not reported in $55.8 \%$ and $52.4 \%$ of the studies respectively.

The modified CONSORT scores per study characteristic are presented in Table 3. The highest modified CONSORT score was found for the Journal of Oral Rehabilitation (80.6\%), which, however, contributed only 2 RCTs, followed by the Clinical Oral Implants Research (73.7\%). The highest modified CONSORT scores chronologically were found in the years 2010-2011. Increased CONSORT scores were also found for RCTs with ethical approval and RCTs with involvement of a statistician/methodologist.

Table 4 presents the results of the univariable and multivariable linear regression analyses. In the univariable analysis, the journal of publication and the involvement of a statistician/methodologist were significantly associated with the CONSORT scores. Similar associations were observed in the multivariable analysis.

Table 5 displays the Jadad scores for the 147 RCTs tabulated by journal. The median Jadad scores ranged from 1.0 (Journal of Prosthetic Dentistry) to 3.5 (Implant Dentistry). 
1

2

3

4

5

6

\section{Discussion}

In this study the reporting quality of RCTs in the fields of prosthodontics and implant dentistry was assessed using a modified CONSORT statement (6) and the Jadad scale (19). The mean modified CONSORT scores ranged from $60.9 \%$ to $80.6 \%$ among the journals included in the study, a finding similar to the scores reported in medical journals $(6,20)$. The Jadad score ranged from 1.0 to 3.5 ; this finding is comparable to other fields in medicine (6). Although all quality score scales have inherent limitations and caution should be used when evaluating reporting quality, the overall score indicates that there is room for improvement.

Pre-study sample size calculation is an important part of designing a trial, and guards against underpowered trials that may result in waste (21-24). In the present study $64.0 \%$ of the RCTs did not report sample size calculation at all, while, $8.2 \%$ of them reported it inadequately. Chan and Altman (25) reported that $73 \%$ of the 519 medical trials published in PubMed in December 2000 did not report sample size calculation. It seems that problematic reporting of pre-study sample size calculations in RCTs is a common finding in the literature $(11,14,26-30)$. Trials with insufficient sample size can be considered unethical, wasteful (21-24) and less credible compared to trials of sufficient size.

The reporting of the randomization process should, ideally, include details about both the methods used to generate the random allocation sequence and any restrictions used during the process. Terms such as "patients were randomly assigned" or "two groups were formed at random" are considered inadequate. The current study showed that the generation of the unpredictable allocation sequence was reported inadequately in $11.6 \%$ of the cases or not at all in $32.7 \%$ of the cases. Altman and Dore (31) studied 80 medical trials published in four leading medical journals and concluded that in $30 \%$ of trials there was no clear evidence that the groups had been randomised.

In dentistry, Montenegro et al. (15) found that only $17 \%$ of the trials published in periodontal journals reported the randomization process adequately. Koletsi et al. (32) found that from 112 clinical trials in the orthodontic literature labeled as RCTs, only $29.5 \%$ were indeed identified as RCTs based on clear descriptions of appropriate random number generation.

Allocation concealment ensures that neither the investigators nor the patients know which treatment the next patient will be allocated to and guards against confounding. Although allocation concealment is always feasible, the results showed that $61.9 \%$ of the included RCTs did not report allocation concealment at all, while $17.7 \%$ of them reported it inadequately. These results are in accordance with previous studies; Pandis et al (18) reported 22\% adequacy in reporting allocation 
concealment among dental journals and Montenegro et al. (15) only 7\% among three periodontal journals.

Another key element in RCT reporting is the description of blinding. Blinding is important to the validity of a trial, as it prevents performance and detection bias, and protects the sequence after allocation. Often the concepts of allocation concealment and blinding are confused. Blinding is especially important for subjective outcomes (e.g. pain scores), as these are more prone to bias. Blinding of the patients and the treatment providers may not always be possible, however, blinding of the assessors and the analysts is $(33,34)$. The results of this study showed that blinding of the various groups was not reported at all in $36.7 \%$ to $89.8 \%$ of the cases. Pandis et al. (18) using a similar scale reported adequate description of blinding in RCTs published in leading dental journals in the range of 0 to $26 \%$.

Statistical methods used for data analysis were not described in $6.1 \%$ whereas $59.2 \%$ of the RCT reports provided an adequate description. These results are similar to a previous assessment in dentistry, which reported that $3 \%$ of the studies provided no description and $51 \%$ provided adequate description of statistical methods (18). Analyses should be pre-specified and ideally described in the trial protocol. Pre-specification allows for the assessment of selective reporting and data driven analysis which can be misleading. A common statistical pitfall is the conduct of multiple tests, which leads to increased type I error (false positive) that can be misleading when associated with selective reporting. It is recommended that subgroup analyses should be pre-specified and kept to the minimum $(35,36)$. The results of the present study showed that $30.6 \%$ of the trials did not describe how this issue was handled, while $34.0 \%$ of the reports described it adequately. Pocock et al. (37) studied 45 medical trials published in three high impact factor medical journals and they reported that multiple endpoints were analyzed without being pre-specified as primary endpoints.

Finally, in the present study $6.1 \%$ and $80.2 \%$ of the trials lacked complete description of estimates and confidence intervals, respectively. Previous studies found inadequate results' reporting in leading medical journals (37). Pandis et al. (18) found that dental trials also suffered from problematic reporting in this area of interest, with lack of description in $3 \%$ and $80 \%$ of the studied trials and adequate description in $62 \%$ and $20 \%$ of them for the complete reporting of the results and for the reporting of confidence intervals respectively. Reporting of estimates and confidence intervals facilitates interpretation in relation to clinical importance. P-values and statistical significance are based on arbitrary cut-off points (i.e. 0.05) and are sensitive to sample size and variance. Small P- 
values are often misinterpreted as showing a clinically important effect and vice versa as trivial and clinically unimportant differences can be statistically significant when sample size is large and variance is small (38).

This study is not free of limitations. A limitation might be that the scoring of trials is always susceptible to some degree of subjectivity. Nevertheless, considerable efforts were made to compensate for inter-rater subjectivity by calibration exercises before study commencement and strict adherence to applied CONSORT guidelines. RCT assessment was limited to high impact factor prosthetic journals and therefore published RCTs in lower impact factor journals or even nonpublished RCTs were excluded. However, we believe that the selected journals constitute a representative or best case scenario sample of the reporting status in the specialty. It should be, also, underlined that incomplete reporting of trials does not necessarily infer low quality of conducting or false methodology (39). Researchers might have designed and conducted a study ideally, but they might have omitted reporting accurately all stages and aspects of their trial due to, for instance, space limitations. Even though RCTs are pivotal for evidence-based dentistry and medicine, they are not free of shortcomings. It is important that they are designed properly, implemented and reported well.

Numerous journals have adopted the CONSORT guidelines and very few have implemented active compliance. The American Journal of Orthodontics and Dentofacial Ortopedics, for instance, has recently implemented a novel approach which includes assessment of compliance at the editorial level and specific recommendations for the authors in order to improve RCT reporting. A preliminary study indicated that this approach has increased dramatically reporting quality (40). In addition the journal has recently adopted a structured report which diverges from the standard IMRaD (Introduction, Methods, Results, Discussion) structure and includes 17 subheadings that lead the report (41). Similar initiatives have been proposed elsewhere (42). The results of the present study indicate that adherence to the CONSORT statement of RCTs in major prosthodontic and implantology journals can be improved.

\section{Conflict of interest}

No funding was obtained for the current study. No conflict of interest declared. 
Tables

Table 1. Characteristics of the 147 included randomized controlled trials

\begin{tabular}{|c|c|c|c|}
\hline Characteristic & Category & $\mathrm{N}$ & $\%$ \\
\hline \multirow[t]{9}{*}{ Journal } & Clin Implant Dent Relat Res & 13 & 8.8 \\
\hline & Clin Oral Implants Res & 46 & 31.3 \\
\hline & Implant Dent & 4 & 2.7 \\
\hline & Int J Oral Maxillofac Implants & 24 & 16.3 \\
\hline & Int J Periodontics Restor Dent & 15 & 10.2 \\
\hline & Int J Prosthodont & 20 & 13.6 \\
\hline & J Dent & 21 & 14.3 \\
\hline & J Oral Rehabil & 2 & 1.4 \\
\hline & $\mathrm{J}$ Prosthet Dent & 2 & 1.4 \\
\hline \multirow[t]{6}{*}{ Year } & 2007 & 4 & 2.7 \\
\hline & 2008 & 12 & 8.2 \\
\hline & 2009 & 13 & 8.8 \\
\hline & 2010 & 41 & 27.9 \\
\hline & 2011 & 42 & 28.6 \\
\hline & 2012 & 35 & 23.8 \\
\hline \multirow[t]{3}{*}{ Continent } & Europe & 86 & 58.5 \\
\hline & Americas & 30 & 20.4 \\
\hline & Asia/Other & 31 & 21.1 \\
\hline \multirow[t]{2}{*}{ Ethics committee approval } & No & 41 & 27.9 \\
\hline & Yes & 106 & 72.1 \\
\hline \multirow[t]{2}{*}{ Statistical significance of main finding } & No & 60 & 40.8 \\
\hline & Yes & 87 & 59.2 \\
\hline \multirow[t]{3}{*}{ Number of authors } & $<4$ & 35 & 23.8 \\
\hline & 4- 6 & 60 & 40.8 \\
\hline & $6 \leq$ & 52 & 35.4 \\
\hline \multirow[t]{2}{*}{ Statistician/methodologist involvement } & No & 92 & 62.6 \\
\hline & Yes & 55 & 37.4 \\
\hline \multirow[t]{2}{*}{ Number of centers } & Single-center & 42 & 28.6 \\
\hline & Multicenter & 105 & 71.4 \\
\hline
\end{tabular}


Table 2. Distribution of consensus scores for the items in the modified CONSORT checklist $(\mathrm{n}=147)$

\begin{tabular}{|c|c|c|c|}
\hline Item & $\begin{array}{l}\text { No description - } \\
\mathrm{n}(\%)\end{array}$ & $\begin{array}{l}\text { Inadequate - } \\
\mathrm{n}(\%)\end{array}$ & $\begin{array}{l}\text { Adequate - } \\
\mathrm{n}(\%)\end{array}$ \\
\hline 1.Justification for the trial for the trial & $15(10.2)$ & $16(10.9)$ & $116(78.9)$ \\
\hline 2.Explicit definition of eligibility criteria & $9(6.1)$ & $26(17.7)$ & $112(76.2)$ \\
\hline $\begin{array}{l}\text { 3.Detailed description of setting/location of recruitment } \\
\text { and data collection }\end{array}$ & $21(14.3)$ & $27(18.4)$ & $99(67.3)$ \\
\hline 4.Details of intervention studied & $0(0.0)$ & $14(9.5)$ & $133(90.5)$ \\
\hline 5.Clear statement of hypothesis or objectives & $2(1.4)$ & $29(19.7)$ & $116(78.9)$ \\
\hline 6.Identification and definition of outcome measures & $2(1.4)$ & $24(16.3)$ & $121(82.3)$ \\
\hline 7.Description of pre-study sample size calculation & $94(63.9)$ & $12(8.2)$ & $41(27.9)$ \\
\hline $\begin{array}{l}\text { 8.Description of the generation of unpredictable } \\
\text { allocation sequence }\end{array}$ & $48(32.7)$ & $17(11.6)$ & $82(55.8)$ \\
\hline 9.Details of any restriction used in randomization & $85(57.8)$ & $13(8.8)$ & $49(33.3)$ \\
\hline 10.Description of allocation concealment & $91(61.9)$ & $26(17.7)$ & $30(20.4)$ \\
\hline $\begin{array}{l}\text { 11.Details of personnel involved in sequence allocation, } \\
\text { enrollment, and assignment }\end{array}$ & $75(51.0)$ & $35(23.8)$ & $37(25.2)$ \\
\hline 12.Details of blinding of participants & $54(36.7)$ & $9(6.1)$ & $84(57.1)$ \\
\hline 13.Details of blinding of treatment providers & $55(37.4)$ & $4(2.7)$ & $88(59.9)$ \\
\hline 14.Details of blinding of assessors & $91(61.9)$ & $18(12.2)$ & $38(25.9)$ \\
\hline 15.Details of blinding of analysts & $132(89.8)$ & $6(4.1)$ & $9(6.1)$ \\
\hline 16.Details of measurement of success of blinding & $143(97.3)$ & $1(0.7)$ & $3(2.0)$ \\
\hline 17.Description of statistical methods & $9(6.1)$ & $51(34.7)$ & $87(59.2)$ \\
\hline $\begin{array}{l}\text { 18.Flow chart describing patient numbers at different } \\
\text { stages }\end{array}$ & $113(76.9)$ & $6(4.1)$ & $28(19.1)$ \\
\hline 19.Clear description of protocol deviations & $55(37.4)$ & $19(12.9)$ & $73(49.7)$ \\
\hline 20.Description of dates of recruitment & $89(60.5)$ & $8(5.4)$ & $50(34.0)$ \\
\hline 21.Details of follow-up & $12(8.2)$ & $17(11.6)$ & $118(80.3)$ \\
\hline 22.Description of baseline characteristics & $19(12.9)$ & $64(43.5)$ & $64(43.5)$ \\
\hline 23.Reporting of intention-to-treat principle & $135(91.8)$ & $3(2.0)$ & $9(6.1)$ \\
\hline 24.Complete reporting of results & $9(6.1)$ & $16(10.9)$ & $122(83.0)$ \\
\hline 25.Reporting of confidence intervals & $118(80.3)$ & $2(1.4)$ & $27(18.4)$ \\
\hline 26.Multiple testing and corrections & $45(30.6)$ & $52(35.4)$ & $50(34.0)$ \\
\hline 27.Description of side effects/adverse effects & $33(22.5)$ & $19(12.9)$ & $95(64.6)$ \\
\hline 28.Trial limitations and weaknesses & $82(55.8)$ & $31(21.1)$ & $34(23.1)$ \\
\hline 29.External validity of trial results & $77(52.4)$ & $49(33.3)$ & $21(14.3)$ \\
\hline 30.Literature review & $1(0.7)$ & $9(6.1)$ & $137(93.2)$ \\
\hline
\end{tabular}


Table 3. Modified CONSORT scores of the 147 included randomized controlled trials

\begin{tabular}{|c|c|c|c|}
\hline Characteristic & Category $(\mathrm{N})$ & Mean & SD \\
\hline \multirow[t]{9}{*}{ Journal } & Clin Implant Dent Rel Res $(n=13)$ & 64.1 & 5.8 \\
\hline & Clin Oral Implants Res $(n=46)$ & 73.7 & 8.3 \\
\hline & Implant Dent $(\mathrm{n}=4)$ & 65.8 & 4.5 \\
\hline & Int $J$ Oral Maxillofac Implants $(n=24)$ & 71.0 & 10.6 \\
\hline & Int J Periodontics Restor Dent $(n=15)$ & 60.9 & 9.3 \\
\hline & Int $J$ Prosthodont $(n=20)$ & 68.0 & 10.9 \\
\hline & J Dent $(n=21)$ & 69.3 & 7.5 \\
\hline & J Oral Rehabil (n=2) & 80.6 & 5.5 \\
\hline & J Prosthet Dent $(n=2)$ & 62.2 & 12.6 \\
\hline \multirow[t]{6}{*}{ Year } & $2007(n=4)$ & 70.0 & 11.4 \\
\hline & $2008(n=12)$ & 64.8 & 10.1 \\
\hline & $2009(n=13)$ & 67.0 & 11.9 \\
\hline & $2010(\mathrm{n}=41)$ & 70.5 & 10.0 \\
\hline & $2011(n=42)$ & 70.5 & 8.6 \\
\hline & $2012(\mathrm{n}=35)$ & 69.1 & 9.5 \\
\hline \multirow[t]{3}{*}{ Country } & Europa $(n=86)$ & 69.6 & 10.1 \\
\hline & Americas $(n=30)$ & 69.8 & 8.8 \\
\hline & Asia/Other $(\mathrm{n}=31)$ & 68.4 & 9.6 \\
\hline \multirow[t]{2}{*}{ Ethics committee approval } & No $(n=41)$ & 67.5 & 10.0 \\
\hline & Yes $(n=106)$ & 70.1 & 9.5 \\
\hline \multirow[t]{2}{*}{ Statistical significance of main finding } & No $(n=41)$ & 70.1 & 9.7 \\
\hline & Yes $(n=106)$ & 68.9 & 9.7 \\
\hline \multirow[t]{3}{*}{ Number of authors } & $<4(\mathrm{n}=35)$ & 70.4 & 9.8 \\
\hline & $4 \leq \mathrm{n}<6(\mathrm{n}=60)$ & 68.9 & 10.0 \\
\hline & $\leq 6(\mathrm{n}=52)$ & 69.2 & 9.4 \\
\hline \multirow{2}{*}{$\begin{array}{l}\text { Statistician/methodologist } \\
\text { involvement }\end{array}$} & No $(n=92)$ & 68.4 & 8.3 \\
\hline & Yes $(n=55)$ & 71.1 & 11.5 \\
\hline \multirow[t]{3}{*}{ Number of centers } & Single-center $(n=42)$ & 68.3 & 9.1 \\
\hline & Multicenter $(\mathrm{n}=105)$ & 69.8 & 9.9 \\
\hline & Total $(\mathrm{n}=147)$ & 69.4 & 9.7 \\
\hline
\end{tabular}

SD, standard deviation. 
Table 4. Univariable and multivariable linear regression-derived coefficients $(\beta)$ and $95 \%$ Confidence Intervals (CIs) for modified CONSORT score as dependent variable for the 147 included randomized controlled trials

\begin{tabular}{|c|c|c|c|c|c|c|c|}
\hline & & \multicolumn{3}{|c|}{ Univariable analysis } & \multicolumn{3}{|c|}{ Multivariable analysis } \\
\hline & & $\bar{\beta}$ & $95 \% \mathrm{CI}$ & $\mathrm{P}$ & $\beta$ & $95 \%$ CI & $\mathrm{P}$ \\
\hline \multicolumn{8}{|l|}{ Journal } \\
\hline & Clin Implant Dent Relat Res & 3.21 & $(-3.53,9.95)$ & 0.35 & 2.75 & $(-3.96,9.46)$ & 0.42 \\
\hline & Clin Oral Implants Res & 12.76 & $(7.47,18.05)$ & $<0.001$ & 12.42 & $(7.08,17.76)$ & $<0.001$ \\
\hline & Other & 7.72 & $(-0.06,15.51)$ & 0.05 & 8.37 & $(0.62,16.11)$ & 0.04 \\
\hline & Int J Oral Maxillofac Implants & 10.08 & $(4.23,15.94)$ & 0.001 & 10.21 & $(4.27,16.15)$ & 0.001 \\
\hline & Int J Prosthodont & 7.11 & $(1.04,13.19)$ & 0.02 & 6.37 & $(0.28,12.46)$ & 0.04 \\
\hline & J Dent & 8.26 & $(2.25,14.28)$ & $<0.01$ & 8.21 & $(2.12,14.32)$ & $<0.01$ \\
\hline \multicolumn{8}{|l|}{ Year } \\
\hline & & 0.64 & $(-0.57,1.85)$ & 0.30 & 0.55 & $(-0.66,1.75)$ & 0.37 \\
\hline \multicolumn{8}{|l|}{ Country } \\
\hline & Europe & 1.21 & $(-2.82,5.25)$ & 0.55 & & & \\
\hline & America & 1.39 & $(-3.54,6.32)$ & 0.56 & & & \\
\hline & Asia/Other & $\begin{array}{l}\text { Baseline } \\
\text { (reference) }\end{array}$ & & & & & \\
\hline \multicolumn{8}{|l|}{$\begin{array}{l}\text { Ethics committee } \\
\text { approval }\end{array}$} \\
\hline & No & $\begin{array}{l}\text { Baseline } \\
\text { (reference) }\end{array}$ & & & & & \\
\hline & Yes & 2.56 & $(-0.95,6.07)$ & 0.15 & 0.42 & $(-3.02,3.86)$ & 0.81 \\
\hline \multicolumn{8}{|l|}{$\begin{array}{l}\text { Statistical } \\
\text { significance of } \\
\text { main finding }\end{array}$} \\
\hline & No & $1.17 \checkmark V$ & $(-2.05,4.39)$ & 0.47 & & & \\
\hline & Yes & $\begin{array}{l}\text { Baseline } \\
\text { (reference) }\end{array}$ & & & & & \\
\hline \multicolumn{8}{|l|}{ Number of authors } \\
\hline & $<4$ & 1.44 & $(-2.66,5.53)$ & 0.49 & & & \\
\hline & $4-6$ & $\begin{array}{l}\text { Baseline } \\
\text { (reference) }\end{array}$ & & & & & \\
\hline & $6 \leq$ & 0.26 & $(-3.38,3.91)$ & 0.87 & & & \\
\hline \multicolumn{8}{|l|}{$\begin{array}{l}\text { Statistician/ } \\
\text { methodologist } \\
\text { involvement }\end{array}$} \\
\hline & No & $\begin{array}{l}\text { Baseline } \\
\text { (reference) }\end{array}$ & & & & & \\
\hline & Yes & 2.77 & $(-0.48,6.01)$ & 0.09 & 3.44 & $(0.29,6.59)$ & 0.03 \\
\hline \multicolumn{8}{|l|}{ Number of centers } \\
\hline & Single-center & $\begin{array}{l}\text { Baseline } \\
\text { (reference) }\end{array}$ & & & & & \\
\hline & Multicenter & 1.54 & $(-1.96,5.04)$ & 0.39 & & & \\
\hline
\end{tabular}


1

2

3

4

5

6

7

8

9

10

11

12

13

14

15

16

17

18

19

20

21

22

23

24

25

26

27

28

29

30

31

32

33

34

35

36

37

38

39

40

41

42

43

44

45

46

47

48

49

50

51

52

53

54

55

56

57

58

59

60

Table 5. Descriptive statistics for the Jadad score of the 147 included RCTs by journal

\begin{tabular}{lll}
\hline Journal $(\mathrm{n})$ & Median & IQR \\
\hline Clin Implant Dent Relat Res $(\mathrm{n}=13)$ & 3.0 & 1.0 \\
Clin Oral Implants Res $(\mathrm{n}=46)$ & 3.0 & 1.0 \\
Implant Dent $(\mathrm{n}=4)$ & 3.5 & 2.0 \\
Int J Oral Maxillofac Implants $(\mathrm{n}=24)$ & 3.0 & 2.0 \\
Int J Periodontics Restor Dent $(\mathrm{n}=15)$ & 2.0 & 1.0 \\
Int J Prosthodont $(\mathrm{n}=20)$ & 2.0 & 1.0 \\
J Dent $(\mathrm{n}=21)$ & 3.0 & 0.0 \\
J Oral Rehabil $(\mathrm{n}=2)$ & 3.0 & 2.0 \\
J Prosthet Dent $(\mathrm{n}=2)$ & 1.0 & 2.0 \\
\hline
\end{tabular}

IQR, interquartile range (Q3-Q1). 


\section{Appendix 1. List of scored papers}

\begin{tabular}{|c|c|c|c|c|c|c|c|c|}
\hline ID & $\begin{array}{l}\text { Yea } \\
\text { r }\end{array}$ & Journal & $\begin{array}{l}\text { Yea } \\
\text { r }\end{array}$ & $\begin{array}{l}\text { Issue(volum } \\
\text { e) }\end{array}$ & First Author & $\begin{array}{l}\text { Jada } \\
\text { d }\end{array}$ & $\begin{array}{l}\text { CONSO } \\
\text { RT }\end{array}$ & $\begin{array}{l}\text { CONSORT } \\
\%\end{array}$ \\
\hline 18 & $\begin{array}{l}201 \\
2\end{array}$ & Clin Oral Implants Res & $\begin{array}{l}201 \\
2\end{array}$ & $23(5)$ & Sisti A & 4 & 67 & 74.4 \\
\hline 22 & $\begin{array}{l}201 \\
2\end{array}$ & Clin Oral Implants Res & $\begin{array}{l}201 \\
2\end{array}$ & 23(5) & Canullo L & 4 & 58 & 64.4 \\
\hline 30 & $\begin{array}{l}201 \\
2\end{array}$ & Clin Oral Implants Res & $\begin{array}{l}201 \\
2\end{array}$ & $23(5)$ & Van Assche N & 3 & 66 & 73.3 \\
\hline 31 & $\begin{array}{l}201 \\
2\end{array}$ & Clin Oral Implants Res & $\begin{array}{l}201 \\
2\end{array}$ & 23(5) & Quirynen M & 3 & 65 & 72.2 \\
\hline 32 & $\begin{array}{l}201 \\
2\end{array}$ & Clin Oral Implants Res & $\begin{array}{l}201 \\
2\end{array}$ & 23(5) & Chongcharoen $\mathrm{N}$ & 3 & 66 & 73.3 \\
\hline 38 & $\begin{array}{l}201 \\
2\end{array}$ & Clin Oral Implants Res & $\begin{array}{l}201 \\
2\end{array}$ & 23(4) & Trombelli L & 5 & 69 & 76.7 \\
\hline 46 & $\begin{array}{l}201 \\
2\end{array}$ & Clin Oral Implants Res & $\begin{array}{l}201 \\
2\end{array}$ & $23(4)$ & Krennmair G & 2 & 60 & 66.7 \\
\hline 47 & $\begin{array}{l}201 \\
2\end{array}$ & Clin Oral Implants Res & $\begin{array}{l}201 \\
2\end{array}$ & $23(4)$ & Romano M & 5 & 61 & 67.8 \\
\hline 48 & $\begin{array}{l}201 \\
2\end{array}$ & Clin Oral Implants Res & $\begin{array}{l}201 \\
2\end{array}$ & $23(4)$ & Elsyad M & 3 & 73 & 81.1 \\
\hline 58 & $\begin{array}{l}201 \\
2\end{array}$ & Clin Oral Implants Res & $\begin{array}{l}201 \\
2\end{array}$ & 23(3) & Lorenzo R & 5 & 83 & 92.2 \\
\hline 78 & $\begin{array}{l}201 \\
2\end{array}$ & Clin Oral Implants Res & $\begin{array}{l}201 \\
2\end{array}$ & $23(2)$ & Hammerle C & 5 & 76 & 84.4 \\
\hline 79 & $\begin{array}{l}201 \\
2\end{array}$ & Clin Oral Implants Res & $\begin{array}{l}201 \\
2\end{array}$ & $23(2)$ & Urban T & 3 & 63 & 70.0 \\
\hline 143 & $\begin{array}{l}201 \\
1\end{array}$ & Clin Oral Implants Res & $\begin{array}{l}201 \\
1\end{array}$ & $22(11)$ & den Hartog L & 5 & 75 & 83.3 \\
\hline 155 & $\begin{array}{l}201 \\
1\end{array}$ & Clin Oral Implants Res & $\begin{array}{l}201 \\
1\end{array}$ & $22(10)$ & Cordaro L & 3 & 70 & 77.8 \\
\hline 162 & $\begin{array}{l}201 \\
1\end{array}$ & Clin Oral Implants Res & $\begin{array}{l}201 \\
1\end{array}$ & $22(10)$ & Enkling $\mathrm{N}$ & 3 & 67 & 74.4 \\
\hline 173 & $\begin{array}{l}201 \\
1\end{array}$ & Clin Oral Implants Res & $\begin{array}{l}201 \\
1\end{array}$ & $22(8)$ & Karabuda Z & 3 & 71 & 78.9 \\
\hline 175 & $\begin{array}{l}201 \\
1\end{array}$ & Clin Oral Implants Res & $\begin{array}{l}201 \\
1\end{array}$ & $22(8)$ & Galindo-Moreno P & 3 & 58 & 64.4 \\
\hline 182 & $\begin{array}{l}201 \\
1\end{array}$ & Clin Oral Implants Res & $\begin{array}{l}201 \\
1\end{array}$ & $22(7)$ & Sakalioglu U & 2 & 54 & 60.0 \\
\hline 193 & $\begin{array}{l}201 \\
1\end{array}$ & Clin Oral Implants Res & $\begin{array}{l}201 \\
1\end{array}$ & $22(6)$ & van Brakel & 2 & 61 & 67.8 \\
\hline 201 & $\begin{array}{l}201 \\
1\end{array}$ & Clin Oral Implants Res & $\begin{array}{l}201 \\
1\end{array}$ & $22(6)$ & Nissan $\mathrm{J}$ & 2 & 54 & 60.0 \\
\hline 202 & $\begin{array}{l}201 \\
1\end{array}$ & Clin Oral Implants Res & $\begin{array}{l}201 \\
1\end{array}$ & $22(6)$ & Bressan E & 1 & 55 & 61.1 \\
\hline 209 & $\begin{array}{l}201 \\
1\end{array}$ & Clin Oral Implants Res & $\begin{array}{l}201 \\
1\end{array}$ & $22(5)$ & Jokstad A & 5 & 80 & 88.9 \\
\hline 211 & $\begin{array}{l}201 \\
1\end{array}$ & Clin Oral Implants Res & $\begin{array}{l}201 \\
1\end{array}$ & $22(5)$ & Chackartchi T & 3 & 63 & 70.0 \\
\hline 222 & $\begin{array}{l}201 \\
1\end{array}$ & Clin Oral Implants Res & $\begin{array}{l}201 \\
1\end{array}$ & $22(5)$ & Heberer S & 3 & 58 & 64.4 \\
\hline 234 & $\begin{array}{l}201 \\
1\end{array}$ & Clin Oral Implants Res & $\begin{array}{l}201 \\
1\end{array}$ & $22(4)$ & Mardas N & 4 & 79 & 87.8 \\
\hline 239 & $\begin{array}{l}201 \\
1\end{array}$ & Clin Oral Implants Res & $\begin{array}{l}201 \\
1\end{array}$ & $22(3)$ & Heitz-Mayfield L & 5 & 69 & 76.7 \\
\hline 241 & $\begin{array}{l}201 \\
1\end{array}$ & Clin Oral Implants Res & $\begin{array}{l}201 \\
1\end{array}$ & 22(3) & Rickert D & 4 & 65 & 72.2 \\
\hline 252 & $\begin{array}{l}201 \\
1\end{array}$ & Clin Oral Implants Res & $\begin{array}{l}201 \\
1\end{array}$ & $22(3)$ & Alsabeeha N & 3 & 74 & 82.2 \\
\hline 272 & $\begin{array}{l}201 \\
1\end{array}$ & Clin Oral Implants Res & $\begin{array}{l}201 \\
1\end{array}$ & $22(1)$ & Tan W & 3 & 64 & 71.1 \\
\hline 278 & $\begin{array}{l}201 \\
1\end{array}$ & Clin Oral Implants Res & $\begin{array}{l}201 \\
1\end{array}$ & $22(1)$ & Galucci G & 4 & 70 & 77.8 \\
\hline 298 & $\begin{array}{l}201 \\
0\end{array}$ & Clin Oral Implants Res & $\begin{array}{l}201 \\
0\end{array}$ & $21(12)$ & Felice P & 5 & 81 & 90.0 \\
\hline 302 & $\begin{array}{l}201 \\
0\end{array}$ & Clin Oral Implants Res & $\begin{array}{l}201 \\
0\end{array}$ & $21(11)$ & Van Der Bilt A & 1 & 53 & 58.9 \\
\hline 304 & $\begin{array}{l}201 \\
0\end{array}$ & Clin Oral Implants Res & $\begin{array}{l}201 \\
0\end{array}$ & $21(11)$ & Van de Velde T & 3 & 66 & 73.3 \\
\hline 309 & $\begin{array}{l}201 \\
0\end{array}$ & Clin Oral Implants Res & $\begin{array}{l}201 \\
0\end{array}$ & $21(11)$ & Urban T & 3 & 61 & 67.8 \\
\hline 313 & $\begin{array}{l}201 \\
0\end{array}$ & Clin Oral Implants Res & $\begin{array}{l}201 \\
0\end{array}$ & $21(11)$ & Koch F & 3 & 64 & 71.1 \\
\hline 318 & $\begin{array}{l}201 \\
0\end{array}$ & Clin Oral Implants Res & $\begin{array}{l}201 \\
0\end{array}$ & $21(9)$ & Pineiro A & 2 & 59 & 65.6 \\
\hline
\end{tabular}




\begin{tabular}{|c|c|c|c|c|c|c|c|c|}
\hline 343 & $\begin{array}{l}201 \\
0\end{array}$ & Clin Oral Implants Res & $\begin{array}{l}201 \\
0\end{array}$ & $21(7)$ & Degidi M & 5 & 73 & 81.1 \\
\hline 344 & $\begin{array}{l}201 \\
0\end{array}$ & Clin Oral Implants Res & $\begin{array}{l}201 \\
0\end{array}$ & $21(7)$ & Mardas N & 4 & 72 & 80.0 \\
\hline 373 & $\begin{array}{l}201 \\
0\end{array}$ & Clin Oral Implants Res & $\begin{array}{l}201 \\
0\end{array}$ & $21(5)$ & Elsyad M & 3 & 68 & 75.6 \\
\hline 374 & $\begin{array}{l}201 \\
0\end{array}$ & Clin Oral Implants Res & $\begin{array}{l}201 \\
0\end{array}$ & $21(5)$ & Zembic A & 4 & 69 & 76.7 \\
\hline 377 & $\begin{array}{l}201 \\
0\end{array}$ & Clin Oral Implants Res & $\begin{array}{l}201 \\
0\end{array}$ & $21(5)$ & Thone-Muhling M & 3 & 59 & 65.6 \\
\hline 381 & $\begin{array}{l}201 \\
0\end{array}$ & Clin Oral Implants Res & $\begin{array}{l}201 \\
0\end{array}$ & $21(5)$ & Pelegrine A & 2 & 60 & 66.7 \\
\hline 426 & $\begin{array}{l}201 \\
0\end{array}$ & Clin Oral Implants Res & $\begin{array}{l}201 \\
0\end{array}$ & $21(2)$ & Park J-C & 4 & 76 & 84.4 \\
\hline 428 & $\begin{array}{l}201 \\
0\end{array}$ & Clin Oral Implants Res & $\begin{array}{l}201 \\
0\end{array}$ & $21(2)$ & Jofre J & 2 & 64 & 71.1 \\
\hline 431 & $\begin{array}{l}201 \\
0\end{array}$ & Clin Oral Implants Res & $\begin{array}{l}201 \\
0\end{array}$ & $21(1)$ & Sanz M & 3 & 69 & 76.7 \\
\hline 444 & $\begin{array}{l}201 \\
0\end{array}$ & Clin Oral Implants Res & $\begin{array}{l}201 \\
0\end{array}$ & $21(1)$ & Canullo L & 4 & 61 & 67.8 \\
\hline 467 & $\begin{array}{l}201 \\
2\end{array}$ & Clin Implant Dent Relat Res & $\begin{array}{l}201 \\
2\end{array}$ & 14(s1) & Al-Zubeidi M & 2 & 59 & 65.6 \\
\hline 503 & $\begin{array}{l}201 \\
2\end{array}$ & Clin Implant Dent Relat Res & $\begin{array}{l}201 \\
2\end{array}$ & $14(2)$ & Enkling $\mathrm{N}$ & 3 & 49 & 54.4 \\
\hline 509 & $\begin{array}{l}201 \\
2\end{array}$ & Clin Implant Dent Relat Res & $\begin{array}{l}201 \\
2\end{array}$ & $14(1)$ & Lindgren C & 2 & 58 & 64.4 \\
\hline 515 & $\begin{array}{l}201 \\
2\end{array}$ & Clin Implant Dent Relat Res & $\begin{array}{l}201 \\
2\end{array}$ & $14(1)$ & Ortorp A & 1 & 61 & 67.8 \\
\hline 521 & $\begin{array}{l}201 \\
2\end{array}$ & Clin Implant Dent Relat Res & $\begin{array}{l}201 \\
2\end{array}$ & $14(1)$ & Enkling $\mathrm{N}$ & 2 & 50 & 55.6 \\
\hline 534 & $\begin{array}{l}201 \\
1\end{array}$ & Clin Implant Dent Relat Res & $\begin{array}{l}201 \\
1\end{array}$ & $13(3)$ & Wenneberg A & 4 & 69 & 76.7 \\
\hline 550 & $\begin{array}{l}201 \\
1\end{array}$ & Clin Implant Dent Relat Res & $\begin{array}{l}201 \\
1\end{array}$ & $13(2)$ & Visser A & 3 & 61 & 67.8 \\
\hline 586 & $\begin{array}{l}201 \\
0\end{array}$ & Clin Implant Dent Relat Res & $\begin{array}{l}201 \\
0\end{array}$ & $12(2)$ & Cehreli M & 4 & 53 & 58.9 \\
\hline 597 & $\begin{array}{l}201 \\
0\end{array}$ & Clin Implant Dent Relat Res & $\begin{array}{l}201 \\
0\end{array}$ & 12(1)s & Turkyilmaz I & 3 & 60 & 66.7 \\
\hline 634 & $\begin{array}{l}200 \\
9\end{array}$ & Clin Implant Dent Relat Res & $\begin{array}{l}200 \\
9\end{array}$ & $11(3)$ & Mericske-Stern R & 2 & 60 & 66.7 \\
\hline 649 & $\begin{array}{l}200 \\
9\end{array}$ & Clin Implant Dent Relat Res & $\begin{array}{l}200 \\
9\end{array}$ & $11(1) \mathrm{s}$ & Canullo L & 3 & 59 & 65.6 \\
\hline 695 & $\begin{array}{l}200 \\
8\end{array}$ & Clin Implant Dent Relat Res & $\begin{array}{l}200 \\
8\end{array}$ & $10(1)$ & Guncu G & 3 & 55 & 61.1 \\
\hline 726 & $\begin{array}{l}200 \\
7\end{array}$ & Clin Implant Dent Relat Res & $\begin{array}{l}200 \\
7\end{array}$ & $9(1)$ & Hall J & 3 & 56 & 62.2 \\
\hline 819 & $\begin{array}{l}201 \\
2\end{array}$ & Int J Oral Maxillofac Implants & $\begin{array}{l}201 \\
2\end{array}$ & $27(2)$ & Wohlfahrt J & 4 & 70 & 77.8 \\
\hline 823 & $\begin{array}{l}201 \\
2\end{array}$ & Int J Oral Maxillofac Implants & $\begin{array}{l}201 \\
2\end{array}$ & $27(2)$ & Ramel C & 4 & 63 & 70.0 \\
\hline 873 & $\begin{array}{l}201 \\
1\end{array}$ & Int J Oral Maxillofac Implants & $\begin{array}{l}201 \\
1\end{array}$ & $26(6)$ & Taguchi T & 2 & 55 & 61.1 \\
\hline 946 & $\begin{array}{l}201 \\
1\end{array}$ & Int J Oral Maxillofac Implants & $\begin{array}{l}201 \\
1\end{array}$ & $26(3)$ & Krennmair G & 1 & 47 & 52.2 \\
\hline 948 & $\begin{array}{l}201 \\
1\end{array}$ & Int J Oral Maxillofac Implants & $\begin{array}{l}201 \\
1\end{array}$ & $26(3)$ & Canullo L & 4 & 67 & 74.4 \\
\hline 949 & $\begin{array}{l}201 \\
1\end{array}$ & Int J Oral Maxillofac Implants & $\begin{array}{l}201 \\
1\end{array}$ & $26(3)$ & Fung $\mathrm{K}$ & 4 & 66 & 73.3 \\
\hline 972 & $\begin{array}{l}201 \\
1\end{array}$ & Int J Oral Maxillofac Implants & $\begin{array}{l}201 \\
1\end{array}$ & $26(2)$ & Heberer S & 2 & 53 & 58.9 \\
\hline 975 & $\begin{array}{l}201 \\
1\end{array}$ & Int J Oral Maxillofac Implants & $\begin{array}{l}201 \\
1\end{array}$ & $26(2)$ & De Kok I & 2 & 62 & 68.9 \\
\hline 989 & $\begin{array}{l}201 \\
1\end{array}$ & Int J Oral Maxillofac Implants & $\begin{array}{l}201 \\
1\end{array}$ & $26(1)$ & Salihoglu U & 2 & 55 & 61.1 \\
\hline 998 & $\begin{array}{l}201 \\
1\end{array}$ & Int J Oral Maxillofac Implants & $\begin{array}{l}201 \\
1\end{array}$ & $26(1)$ & Pieri $\mathrm{F}$ & 5 & 71 & 78.9 \\
\hline $\begin{array}{l}102 \\
2\end{array}$ & $\begin{array}{l}201 \\
0\end{array}$ & Int J Oral Maxillofac Implants & $\begin{array}{l}201 \\
0\end{array}$ & $25(6)$ & Jofre J & 4 & 65 & 72.2 \\
\hline $\begin{array}{l}107 \\
8\end{array}$ & $\begin{array}{l}201 \\
0\end{array}$ & Int J Oral Maxillofac Implants & $\begin{array}{l}201 \\
0\end{array}$ & $25(4)$ & Merli M & 5 & 85 & 94.4 \\
\hline $\begin{array}{l}109 \\
9\end{array}$ & $\begin{array}{l}201 \\
0\end{array}$ & Int J Oral Maxillofac Implants & $\begin{array}{l}201 \\
0\end{array}$ & $25(3)$ & van Kesteren C & 2 & 60 & 66.7 \\
\hline $\begin{array}{l}121 \\
3\end{array}$ & $\begin{array}{l}200 \\
9\end{array}$ & Int J Oral Maxillofac Implants & $\begin{array}{l}200 \\
9\end{array}$ & $24(5)$ & Aimetti M & 3 & 63 & 70.0 \\
\hline $\begin{array}{l}127 \\
8\end{array}$ & $\begin{array}{l}200 \\
9\end{array}$ & Int J Oral Maxillofac Implants & $\begin{array}{l}200 \\
9\end{array}$ & $24(2)$ & Prosper L & 5 & 80 & 88.9 \\
\hline 133 & 200 & Int J Oral Maxillofac Implants & 200 & $23(5)$ & Covani U & 3 & 58 & 64.4 \\
\hline
\end{tabular}




\begin{tabular}{|c|c|c|c|c|c|c|c|c|}
\hline 6 & 8 & & 8 & & & & & \\
\hline $\begin{array}{l}133 \\
9\end{array}$ & $\begin{array}{l}200 \\
8\end{array}$ & Int J Oral Maxillofac Implants & $\begin{array}{l}200 \\
8\end{array}$ & $23(5)$ & Cannizzaro G & 5 & 79 & 87.8 \\
\hline $\begin{array}{l}134 \\
7\end{array}$ & $\begin{array}{l}200 \\
8\end{array}$ & Int J Oral Maxillofac Implants & $\begin{array}{l}200 \\
8\end{array}$ & 23(5) & Shahidi P & 3 & 60 & 66.7 \\
\hline $\begin{array}{l}137 \\
3\end{array}$ & $\begin{array}{l}200 \\
8\end{array}$ & Int J Oral Maxillofac Implants & $\begin{array}{l}200 \\
8\end{array}$ & 23(4) & Schropp L & 3 & 56 & 62.2 \\
\hline $\begin{array}{l}137 \\
5\end{array}$ & $\begin{array}{l}200 \\
8\end{array}$ & Int J Oral Maxillofac Implants & $\begin{array}{l}200 \\
8\end{array}$ & 23(4) & Crespi R & 2 & 57 & 63.3 \\
\hline $\begin{array}{l}138 \\
7\end{array}$ & $\begin{array}{l}200 \\
8\end{array}$ & Int J Oral Maxillofac Implants & $\begin{array}{l}200 \\
8\end{array}$ & 23(3) & Schincaglia G & 3 & 69 & 76.7 \\
\hline $\begin{array}{l}140 \\
8\end{array}$ & $\begin{array}{l}200 \\
8\end{array}$ & Int J Oral Maxillofac Implants & $\begin{array}{l}200 \\
8\end{array}$ & 23(2) & Morneburg T & 2 & 57 & 63.3 \\
\hline $\begin{array}{l}146 \\
9\end{array}$ & $\begin{array}{l}200 \\
7\end{array}$ & Int J Oral Maxillofac Implants & $\begin{array}{l}200 \\
7\end{array}$ & $22(5)$ & Oates T & 2 & 57 & 63.3 \\
\hline $\begin{array}{l}147 \\
8\end{array}$ & $\begin{array}{l}200 \\
7\end{array}$ & Int J Oral Maxillofac Implants & $\begin{array}{l}200 \\
7\end{array}$ & 22(5) & Testori T & 5 & 78 & 86.7 \\
\hline $\begin{array}{l}151 \\
5\end{array}$ & $\begin{array}{l}201 \\
2\end{array}$ & Implant Dent & $\begin{array}{l}201 \\
2\end{array}$ & $21(3)$ & Gadallah A & 5 & 65 & 72.2 \\
\hline $\begin{array}{l}154 \\
7\end{array}$ & $\begin{array}{l}201 \\
2\end{array}$ & Implant Dent & $\begin{array}{l}201 \\
2\end{array}$ & $21(3)$ & Gadallah A & 4 & 56 & 62.2 \\
\hline $\begin{array}{l}171 \\
9\end{array}$ & $\begin{array}{l}201 \\
0\end{array}$ & Implant Dent & $\begin{array}{l}201 \\
0\end{array}$ & 19(2) & Basha A & 2 & 57 & 63.3 \\
\hline $\begin{array}{l}179 \\
9\end{array}$ & $\begin{array}{l}200 \\
9\end{array}$ & Implant Dent & $\begin{array}{l}200 \\
9\end{array}$ & 18(1) & Guncu G & 3 & 59 & 65.6 \\
\hline $\begin{array}{l}191 \\
8\end{array}$ & $\begin{array}{l}201 \\
2\end{array}$ & J Dent & $\begin{array}{l}201 \\
2\end{array}$ & $40(5)$ & $\begin{array}{l}\text { de Sousa Barbosa } \\
\mathrm{R}\end{array}$ & 2 & 54 & 60.0 \\
\hline $\begin{array}{l}196 \\
7\end{array}$ & $\begin{array}{l}201 \\
2\end{array}$ & J Dent & $\begin{array}{l}201 \\
2\end{array}$ & $40(1)$ & West $\mathrm{N}$ & 4 & 79 & 87.8 \\
\hline $\begin{array}{l}198 \\
0\end{array}$ & $\begin{array}{l}201 \\
1\end{array}$ & J Dent & $\begin{array}{l}201 \\
1\end{array}$ & $39(s 3)$ & Moffa E & 3 & 58 & 64.4 \\
\hline $\begin{array}{l}200 \\
4\end{array}$ & $\begin{array}{l}201 \\
1\end{array}$ & J Dent & $\begin{array}{l}201 \\
1\end{array}$ & $39(11)$ & Lopez-Jornet M & 3 & 60 & 66.7 \\
\hline $\begin{array}{l}200 \\
6\end{array}$ & $\begin{array}{l}201 \\
1\end{array}$ & J Dent & $\begin{array}{l}201 \\
1\end{array}$ & $39(11)$ & Kitasako $\mathrm{Y}$ & 4 & 65 & 72.2 \\
\hline $\begin{array}{l}201 \\
5\end{array}$ & $\begin{array}{l}201 \\
1\end{array}$ & J Dent & $\begin{array}{l}201 \\
1\end{array}$ & $39(10)$ & Ren Y-F & 3 & 58 & 64.4 \\
\hline $\begin{array}{l}203 \\
8\end{array}$ & $\begin{array}{l}201 \\
1\end{array}$ & J Dent & $\begin{array}{l}201 \\
1\end{array}$ & $39(7)$ & Huth K & 4 & 69 & 76.7 \\
\hline $\begin{array}{l}204 \\
2\end{array}$ & $\begin{array}{l}201 \\
1\end{array}$ & J Dent & $\begin{array}{l}201 \\
1\end{array}$ & $39(7)$ & Nelson-Filho P & 3 & 63 & 70.0 \\
\hline $\begin{array}{l}204 \\
3\end{array}$ & $\begin{array}{l}201 \\
1\end{array}$ & J Dent & $\begin{array}{l}201 \\
1\end{array}$ & $39(7)$ & Shen $\mathrm{P}$ & 3 & 70 & 77.8 \\
\hline $\begin{array}{l}205 \\
6\end{array}$ & $\begin{array}{l}201 \\
1\end{array}$ & J Dent & $\begin{array}{l}201 \\
1\end{array}$ & $39(5)$ & Wirsching $\mathrm{E}$ & 2 & 53 & 58.9 \\
\hline $\begin{array}{l}211 \\
4\end{array}$ & $\begin{array}{l}201 \\
0\end{array}$ & J Dent & $\begin{array}{l}201 \\
0\end{array}$ & $38(12)$ & Meireles S & 5 & 70 & 77.8 \\
\hline $\begin{array}{l}212 \\
2\end{array}$ & $\begin{array}{l}201 \\
0\end{array}$ & J Dent & $\begin{array}{l}201 \\
0\end{array}$ & $38(12)$ & Huth K & 3 & 67 & 74.4 \\
\hline $\begin{array}{l}212 \\
5\end{array}$ & $\begin{array}{l}201 \\
0\end{array}$ & J Dent & $\begin{array}{l}201 \\
0\end{array}$ & $38(11)$ & Hyde T & 5 & 66 & 73.3 \\
\hline $\begin{array}{l}213 \\
1\end{array}$ & $\begin{array}{l}201 \\
0\end{array}$ & J Dent & $\begin{array}{l}201 \\
0\end{array}$ & $38(11)$ & Pan S & 3 & 62 & 68.9 \\
\hline $\begin{array}{l}217 \\
3\end{array}$ & $\begin{array}{l}201 \\
0\end{array}$ & J Dent & $\begin{array}{l}201 \\
0\end{array}$ & $38(7)$ & Syrek A & 3 & 54 & 60.0 \\
\hline $\begin{array}{l}218 \\
1\end{array}$ & $\begin{array}{l}201 \\
0\end{array}$ & J Dent & $\begin{array}{l}201 \\
0\end{array}$ & $38(6)$ & dos Santos M & 3 & 64 & 71.1 \\
\hline $\begin{array}{l}218 \\
4\end{array}$ & $\begin{array}{l}201 \\
0\end{array}$ & J Dent & $\begin{array}{l}201 \\
0\end{array}$ & $38(6)$ & Banerjee A & 3 & 58 & 64.4 \\
\hline $\begin{array}{l}218 \\
9\end{array}$ & $\begin{array}{l}201 \\
0\end{array}$ & J Dent & $\begin{array}{l}201 \\
0\end{array}$ & $38(6)$ & Mcdonald E & 3 & 58 & 64.4 \\
\hline $\begin{array}{l}221 \\
9\end{array}$ & $\begin{array}{l}201 \\
0\end{array}$ & J Dent & $\begin{array}{l}201 \\
0\end{array}$ & $38(3)$ & Emami $\mathrm{E}$ & 2 & 64 & 71.1 \\
\hline $\begin{array}{l}225 \\
2\end{array}$ & $\begin{array}{l}201 \\
0\end{array}$ & J Dent & $\begin{array}{l}201 \\
0\end{array}$ & $38 s 3$ & Mason S & 3 & 52 & 57.8 \\
\hline $\begin{array}{l}225 \\
3\end{array}$ & $\begin{array}{l}201 \\
0\end{array}$ & J Dent & $\begin{array}{l}201 \\
0\end{array}$ & $38 s 3$ & Maggio B & 2 & 63 & 70.0 \\
\hline $\begin{array}{l}235 \\
2\end{array}$ & $\begin{array}{l}201 \\
1\end{array}$ & J Prosthet Dent & $\begin{array}{l}201 \\
1\end{array}$ & $106(1)$ & Burns D & 2 & 64 & 71.1 \\
\hline $\begin{array}{l}242 \\
4\end{array}$ & $\begin{array}{l}201 \\
0\end{array}$ & J Prosthet Dent & $\begin{array}{l}201 \\
0\end{array}$ & $104(6)$ & Damodara E & 0 & 48 & 53.3 \\
\hline $\begin{array}{l}261 \\
6\end{array}$ & $\begin{array}{l}201 \\
1\end{array}$ & J Oral Rehab & $\begin{array}{l}201 \\
1\end{array}$ & $38(10)$ & Nilsson $\mathrm{H}$ & 2 & 69 & 76.7 \\
\hline $\begin{array}{l}275 \\
9\end{array}$ & $\begin{array}{l}201 \\
0\end{array}$ & J Oral Rehab & $\begin{array}{l}201 \\
0\end{array}$ & $37(7)$ & Kimoto S & 4 & 76 & 84.4 \\
\hline $\begin{array}{l}285 \\
2\end{array}$ & $\begin{array}{l}201 \\
2\end{array}$ & Int J Prosth & $\begin{array}{l}201 \\
2\end{array}$ & $25(4)$ & Gjengedal H & 2 & 53 & 58.9 \\
\hline
\end{tabular}




\begin{tabular}{|c|c|c|c|c|c|c|c|c|}
\hline $\begin{array}{l}286 \\
5\end{array}$ & 201 & Int J Prosth & $\begin{array}{l}201 \\
2\end{array}$ & $25(3)$ & Stober T & 2 & 53 & 58.9 \\
\hline $\begin{array}{l}286 \\
7\end{array}$ & $\begin{array}{l}201 \\
2\end{array}$ & Int J Prosth & $\begin{array}{l}201 \\
2\end{array}$ & $25(3)$ & Sagirkaya E & 2 & 63 & 70.0 \\
\hline $\begin{array}{l}286 \\
8\end{array}$ & $\begin{array}{l}201 \\
2\end{array}$ & Int J Prosth & $\begin{array}{l}201 \\
2\end{array}$ & $25(3)$ & Volpato Sanita P & 3 & 70 & 77.8 \\
\hline $\begin{array}{l}288 \\
6\end{array}$ & $\begin{array}{l}201 \\
2\end{array}$ & Int J Prosth & $\begin{array}{l}201 \\
2\end{array}$ & $25(2)$ & Elsyad M & 2 & 54 & 60.0 \\
\hline $\begin{array}{l}288 \\
7\end{array}$ & $\begin{array}{l}201 \\
2\end{array}$ & Int J Prosth & $\begin{array}{l}201 \\
2\end{array}$ & $25(2)$ & $\begin{array}{l}\text { Machado de } \\
\text { Andrade I }\end{array}$ & 1 & 49 & 54.4 \\
\hline $\begin{array}{l}294 \\
7\end{array}$ & $\begin{array}{l}201 \\
1\end{array}$ & Int J Prosth & $\begin{array}{l}201 \\
1\end{array}$ & $24(4)$ & Zicari F & 3 & 72 & 80.0 \\
\hline $\begin{array}{l}299 \\
3\end{array}$ & $\begin{array}{l}201 \\
1\end{array}$ & Int J Prosth & $\begin{array}{l}201 \\
1\end{array}$ & $24(1)$ & Cehreli M & 2 & 62 & 68.9 \\
\hline $\begin{array}{l}300 \\
7\end{array}$ & $\begin{array}{l}201 \\
0\end{array}$ & Int J Prosth & $\begin{array}{l}201 \\
0\end{array}$ & $23(6)$ & Larsson C & 0 & 49 & 54.4 \\
\hline $\begin{array}{l}303 \\
0\end{array}$ & $\begin{array}{l}201 \\
0\end{array}$ & Int J Prosth & $\begin{array}{l}201 \\
0\end{array}$ & $23(4)$ & Cune $\mathrm{M}$ & 0 & 52 & 57.8 \\
\hline $\begin{array}{l}305 \\
5\end{array}$ & $\begin{array}{l}201 \\
0\end{array}$ & Int J Prosth & $\begin{array}{l}201 \\
0\end{array}$ & $23(3)$ & Klat-amnuay S & 3 & 79 & 87.8 \\
\hline $\begin{array}{l}306 \\
0\end{array}$ & $\begin{array}{l}201 \\
0\end{array}$ & Int J Prosth & $\begin{array}{l}201 \\
0\end{array}$ & $23(2)$ & Kimoto $\mathrm{S}$ & 4 & 76 & 84.4 \\
\hline $\begin{array}{l}308 \\
6\end{array}$ & $\begin{array}{l}200 \\
9\end{array}$ & Int J Prosth & $\begin{array}{l}200 \\
9\end{array}$ & $22(6)$ & Sailer I & 2 & 57 & 63.3 \\
\hline $\begin{array}{l}312 \\
0\end{array}$ & $\begin{array}{l}200 \\
9\end{array}$ & Int J Prosth & $\begin{array}{l}200 \\
9\end{array}$ & $22(4)$ & Walton $\mathrm{J}$ & 4 & 78 & 86.7 \\
\hline $\begin{array}{l}312 \\
6\end{array}$ & $\begin{array}{l}200 \\
9\end{array}$ & Int J Prosth & $\begin{array}{l}200 \\
9\end{array}$ & $22(4)$ & Pradies G & 2 & 62 & 68.9 \\
\hline $\begin{array}{l}314 \\
3\end{array}$ & $\begin{array}{l}200 \\
9\end{array}$ & Int J Prosth & $\begin{array}{l}200 \\
9\end{array}$ & 22(3) & Cannulo L & 3 & 69 & 76.7 \\
\hline $\begin{array}{l}314 \\
8\end{array}$ & $\begin{array}{l}200 \\
9\end{array}$ & Int J Prosth & $\begin{array}{l}200 \\
9\end{array}$ & $22(3)$ & Haim $\mathrm{M}$ & 2 & 57 & 63.3 \\
\hline $\begin{array}{l}321 \\
9\end{array}$ & $\begin{array}{l}200 \\
8\end{array}$ & Int J Prosth & $\begin{array}{l}200 \\
8\end{array}$ & $21(4)$ & Berg $\mathrm{E}$ & 2 & 58 & 64.4 \\
\hline $\begin{array}{l}322 \\
1\end{array}$ & $\begin{array}{l}200 \\
8\end{array}$ & Int J Prosth & $\begin{array}{l}200 \\
8\end{array}$ & $21(4)$ & Luthardt R & 2 & 50 & 55.6 \\
\hline $\begin{array}{l}329 \\
8\end{array}$ & $\begin{array}{l}200 \\
7\end{array}$ & Int J Prosth & $\begin{array}{l}200 \\
7\end{array}$ & $20(5)$ & Naumann M & 2 & 61 & 67.8 \\
\hline $\begin{array}{l}333 \\
0\end{array}$ & $\begin{array}{l}201 \\
2\end{array}$ & $\begin{array}{l}\text { Int J Periodontics Restorative } \\
\text { Dent }\end{array}$ & $\begin{array}{l}201 \\
2\end{array}$ & $32(4)$ & Cardaropoli D & 4 & 67 & 74.4 \\
\hline $\begin{array}{l}334 \\
7\end{array}$ & $\begin{array}{l}201 \\
2\end{array}$ & $\begin{array}{l}\text { Int J Periodontics Restorative } \\
\text { Dent }\end{array}$ & $\begin{array}{l}201 \\
2\end{array}$ & $32(3)$ & Riza Certin A & 0 & 51 & 56.7 \\
\hline $\begin{array}{l}335 \\
1\end{array}$ & $\begin{array}{l}201 \\
2\end{array}$ & $\begin{array}{l}\text { Int J Periodontics Restorative } \\
\text { Dent }\end{array}$ & $\begin{array}{l}201 \\
2\end{array}$ & $32(3)$ & Griffiths $\mathrm{G}$ & 1 & 56 & 62.2 \\
\hline $\begin{array}{l}335 \\
8\end{array}$ & $\begin{array}{l}201 \\
2\end{array}$ & $\begin{array}{l}\text { Int J Periodontics Restorative } \\
\text { Dent }\end{array}$ & $\begin{array}{l}201 \\
2\end{array}$ & $32(2)$ & Jankovic K & 2 & 60 & 66.7 \\
\hline $\begin{array}{l}336 \\
1\end{array}$ & $\begin{array}{l}201 \\
2\end{array}$ & $\begin{array}{l}\text { Int J Periodontics Restorative } \\
\text { Dent }\end{array}$ & $\begin{array}{l}201 \\
2\end{array}$ & $32(2)$ & Margossian $\mathrm{P}$ & 3 & 57 & 63.3 \\
\hline $\begin{array}{l}337 \\
7\end{array}$ & $\begin{array}{l}201 \\
2\end{array}$ & $\begin{array}{l}\text { Int J Periodontics Restorative } \\
\text { Dent }\end{array}$ & $\begin{array}{l}201 \\
2\end{array}$ & $32(1)$ & Cordaro L & 2 & 73 & 81.1 \\
\hline $\begin{array}{l}338 \\
8\end{array}$ & $\begin{array}{l}201 \\
1\end{array}$ & $\begin{array}{l}\text { Int J Periodontics Restorative } \\
\text { Dent }\end{array}$ & $\begin{array}{l}201 \\
1\end{array}$ & $31(6)$ & Froum S & 2 & 59 & 65.6 \\
\hline $\begin{array}{l}344 \\
8\end{array}$ & $\begin{array}{l}201 \\
1\end{array}$ & $\begin{array}{l}\text { Int J Periodontics Restorative } \\
\text { Dent }\end{array}$ & $\begin{array}{l}201 \\
1\end{array}$ & $31(2)$ & Rasperini G & 1 & 50 & 55.6 \\
\hline $\begin{array}{l}350 \\
4\end{array}$ & $\begin{array}{l}201 \\
0\end{array}$ & $\begin{array}{l}\text { Int J Periodontics Restorative } \\
\text { Dent }\end{array}$ & $\begin{array}{l}201 \\
0\end{array}$ & $30(3)$ & Rasperini G & 1 & 57 & 63.3 \\
\hline $\begin{array}{l}351 \\
5\end{array}$ & $\begin{array}{l}201 \\
0\end{array}$ & $\begin{array}{l}\text { Int J Periodontics Restorative } \\
\text { Dent }\end{array}$ & $\begin{array}{l}201 \\
0\end{array}$ & $30(2)$ & Wu S-Y & 0 & 51 & 56.7 \\
\hline $\begin{array}{l}353 \\
5\end{array}$ & $\begin{array}{l}200 \\
9\end{array}$ & $\begin{array}{l}\text { Int J Periodontics Restorative } \\
\text { Dent }\end{array}$ & $\begin{array}{l}200 \\
9\end{array}$ & $29(6)$ & Trammel K & 3 & 49 & 54.4 \\
\hline $\begin{array}{l}357 \\
9\end{array}$ & $\begin{array}{l}200 \\
9\end{array}$ & $\begin{array}{l}\text { Int J Periodontics Restorative } \\
\text { Dent }\end{array}$ & $\begin{array}{l}200 \\
9\end{array}$ & $29(2)$ & Haghighati F & 0 & 44 & 48.9 \\
\hline $\begin{array}{l}358 \\
9\end{array}$ & $\begin{array}{l}200 \\
9\end{array}$ & $\begin{array}{l}\text { Int J Periodontics Restorative } \\
\text { Dent }\end{array}$ & $\begin{array}{l}200 \\
9\end{array}$ & $29(1)$ & Cardaropoli D & 2 & 47 & 52.2 \\
\hline $\begin{array}{l}360 \\
7\end{array}$ & $\begin{array}{l}200 \\
8\end{array}$ & $\begin{array}{l}\text { Int J Periodontics Restorative } \\
\text { Dent }\end{array}$ & $\begin{array}{l}200 \\
8\end{array}$ & $28(5)$ & Merli M & 2 & 59 & 65.6 \\
\hline $\begin{array}{l}361 \\
9\end{array}$ & $\begin{array}{l}200 \\
8\end{array}$ & $\begin{array}{l}\text { Int J Periodontics Restorative } \\
\text { Dent }\end{array}$ & $\begin{array}{l}200 \\
8\end{array}$ & $28(4)$ & Jung $R$ & 1 & 42 & 46.7 \\
\hline
\end{tabular}




\section{References}

1. Juni P, Altman DG, Egger M. Systematic reviews in health care: assessing the quality of controlled clinical trials. BMJ. 2001;323:42-46.

2. Moher D, Hopewell S, Schulz KF, Montori V, Gøtzsche PC, Devereaux PJ et al. CONSORT 2010 Explanation and Elaboration: updated guidelines for reporting parallel group randomised trials. BMJ. 2010;340:c869.

3. Schulz KF, Chalmers I, Grimes DA, Altman DG. Assessing the quality of randomization from reports of controlled trials published in obstetrics and gynecology journals. JAMA. 1994;272:125-128.

4. Moher D, Jadad AR, Nichol G, Penman M, Tugwell P, Walsh S. Assessing the quality of randomized controlled trials: an annotated bibliography of scales and checklists. Control Clin Trials. 1995;16:6273.

5. Balasubramanian SP, Wiener M, Alshameeri Z, Tiruvoipati R, Elbourne D, Reed MW. Standards of reporting of randomized controlled trials in general surgery: can we do better? Ann Surg. 2006;244:663-667.

6. Tiruvoipati R, Balasubramanian SP, Atturu G, Peek GJ, Elbourne D. Improving the quality of reporting randomized controlled trials in cardiothoracic surgery: the way forward. J Thorac Cardiovasc Surg. 2006;132:233-240.

7. Glasziou P, Altman DG, Bossuyt P, Boutron I, Clarke M, Julious S et al. Reducing waste from incomplete or unusable reports of biomedical research. Lancet. 2014;383:267-276.

8. The CONSORT Website. CONSORT endorsers-journals. http://www.consortstatement.org/aboutconsort/consort-endorsement/consort-endorsers journals/.

9. Turner L, Shamseer L, Altman DG, Schulz KF, Moher D. Does use of the CONSORT Statement impact the completeness of reporting of randomised controlled trials published in medical journals? A Cochrane review. Cochrane Database Syst Rev. 2012;doi: 10.1186/2046-4053-1-60.

10. Antczak AA, Tang J, Chalmers TC. Quality assessment of randomized control trials in dental research. II. Results: Periodontal research. J Periodontal Res. 1986;21:315-321.

11. Prihoda TJ, Schelb E, Jones JD. The reporting of statistical inferences in selected prosthodontic journals. J Prosthod.1992;1:51-56.

12. Dumbrigue HB, Jones JS, Esquivel JF. Control of bias in randomized controlled trials published in prosthodontic journals. J Prosthet Dent. 2001;86: 592-596. 
13. Esposito M, Coulthard P, Worthington HV, Jokstad A. Quality assessment of randomized controlled trials of oral implants. Int J Oral Maxillofac Implants. 2001;16:783-792.

14. Jokstad A, Esposito M, Coulthard P, Worthington HV. The reporting of randomized controlled trials in prosthodontics. Int J Prosthodont. 2002;15:230-242.

15. Montenegro R, Needleman I, Moles D, Tonetti M. Quality of RCTs in periodontology. A systematic review. J Dent Res. 2002;81:866-870.

16. Sjögren $\mathrm{P}$, Halling A. Quality of reporting randomised clinical trials in dental and medical research. $\mathrm{Br}$ Dent J. 2002;192:100-103.

17. Harrison JE. Clinical trials in orthodontics II: Assessment of the quality of American Journal of Dentistry, Vol. 21, No. 1, February, 2008 reporting of clinical trials published in three orthodontic journals between 1989 and 1998. J Orthod. 2003;30:309-315.

18. Pandis N, Polychronopoulou A, Eliades T. An assessment of quality characteristics of randomised control trials published in dental journals. J Dent. 2010;38:713-721.

19. Jadad AR, Moore RA, Carroll D, Jenkinson C, Reynolds DJ, Gavaghan DJ et al. Assessing the quality of reports of randomized clinical trials: is blinding necessary? Control Clin Trials. 1996;17:1-12.

20. Moher D, Jones A, Lepage L. Use of the CONSORT statement and quality of reports of randomized trials: a comparative before-and-after evaluation. JAMA. 2001;285:1992-1995.

21. Al-Shahi Salman R, Beller E, Kagan J, Hemminki E, Phillips RS, Savulescu J et al. Increasing value and reducing waste in biomedical research regulation and management. Lancet. 2014;383:176-185.

22. Chan AW, Song F, Vickers A, Jefferson T, Dickersin K, Gøtzsche PC et al. Increasing value and reducing waste: addressing inaccessible research. Lancet. 2014;383:257-266.

23. Ioannidis JP, Greenland S, Hlatky MA, Khoury MJ, Macleod MR, Moher D et al. Increasing value and reducing waste in research design, conduct, and analysis. Lancet. 2014;383:166-175.

24. Macleod MR, Michie S, Roberts I, Dirnagl U, Chalmers I, Ioannidis JP et al. Biomedical research: increasing value, reducing waste. Lancet. 2014;383:101-104.

25. Chan AW, Altman DG. Epidemiology and reporting of randomised trials published in PubMed journals. Lancet. 2005;365:1159-1162.

26. Hujoel PP, Baab DA, DeRouen TA. The power of tests to detect differences between periodontal treatments in published studies. J Clin Periodontol. 1992;19:779-784.

27. Gunsolley JC, Elswick RK, Davenport JM. Equivalence and superiority testing in regeneration clinical trials. J Periodontol. 1998;69:521-527. 
28. Lesaffre E, Garcia Zattera MJ, Redmond C, Huber H, Needleman I. Reported methodological quality of split-mouth studies. J Clin Periodontol. 2007;34:756-761.

29. Lempesi E, Koletsi D, Fleming PS, Pandis N. The reporting quality of randomized controlled trials in orthodontics. J Evid Based Dent Pract. 2014;14:46-52.

30. Fleming PS, Lynch CD, Pandis N. Randomized controlled trials in dentistry: common pitfalls and how to avoid them. J Dent. 2014;42:908-914.

31. Altman DG, Dore CJ. Randomisation and baseline comparisons in clinical trials. Lancet. 1990;335:149-153.

32. Koletsi D, Pandis N, Polychronopoulou A, Eliades T. What's in a title? An assessment of whether randomized controlled trial in a title means that it is one. Am J Orthod Dentofacial Orthop. 2012;141:679-685.

33. Schulz KF, Chalmers I, Altman DG. The landscape and lexicon of blinding in randomized trials. Ann Intern Med. 2002;136:254-259.

34. Savović J, Jones HE, Altman DG, Harris RJ, Jüni P, Pildal J et al. Influence of reported study design characteristics on intervention effect estimates from randomized, controlled trials. Ann Intern Med. $2012 ; 157: 429-438$.

35. Pandis N. Multiplicity 1: subgroup analyses. Am J Orthod Dentofacial Orthop. 2013;143:439-441.

36. Sun X, Ioannidis JP, Agoritsas T, Alba AC, Guyatt G. How to use a subgroup analysis: users' guide to the medical literature. JAMA. 2014;311:405-411.

37. Pocock SJ, Hughes MD, Lee RJ. Statistical problems in the reporting of clinical trials. A survey of three medical journals. New Eng J Med. 1987;317:426-432.

38. Rothman KJ. Six persistent research misconceptions. J Gen Intern Med. 2014;29:1060-4.

39. Soares HP, Daniels S, Kumar A, Clarke M, Scott C, Swann S et al. Bad reporting does not mean bad methods for randomised trials: observational study of randomised controlled trials performed by the Radiation Therapy Oncology Group. BMJ. 2004;328:22-24.

40. Pandis N, Shamseer L, Kokich V, Fleming PS, Moher D. Implementation of a strategy to improve adherence to the CONSORT guidelines by a dental specialty journal. J Clinical Epidemiology pii: S0895-4356(14)00114-0. doi: 10.1016/j.jclinepi.2014.04.001. [Epub ahead of print]

41. Guidelines for Randomised Clinical trials. http://www.ajodo.org/content/authorinfo\#idp1848752

42. Altman DG. Making research articles fit for purpose: structured reporting of key methods and findings. Trials. 2015 Feb 20;16(1):53. doi:10.1186/s13063-015-0575-7 
1

2

3

4

5

6

7

8

9

10

11

12

13

14

15

16

17

18

19

20

21

22

23

24

25

26

27

28

29

30

31

32

33

34

35

36

37

38

39

40

41

42

43

44

45

46

47

48

49

50

51

52

53

54

55

56

57

58

59

60 